\title{
Assessing the adherence to and the therapeutic effectiveness of hypolipidemic agents in a population of patients in Brazil: a retrospective cohort study
}

\author{
Cássia CUNICO, Geraldo PICHETH, Cassyano J. CORRER, Marileia SCARTEZINI.
}

Received (first version): 23-Oct-2013 Accepted: 27-May-2014

\begin{abstract}
${ }^{*}$
Objective: to evaluate the relation between patient adherence and therapeutic effectiveness of hypolipidemic agents in clinical practice.

Methods: A retrospective cohort study of 417 patients using hypolipidemic drugs (simvastatin, atorvastatin) between 2003 and 2010 was performed. The population studied consists of patients assisted by the Public Health Service in the far-west region of the State of Santa Catarina, Brazil. The Medication Possession Ratio obtained from pharmacy refill data was used to measure patient adherence. Therapeutic effectiveness was evaluated based on the difference obtained in the serum levels of total cholesterol, LDL-cholesterol, HDLcholesterol and triglycerides, before and after taking the drug, in an average time of 8.3 months.

Results: Following the treatment with hypolipidemic agents, it has been observed a reduction of $14.3 \%$ for total cholesterol, $19.6 \%$ for LDL-cholesterol, and $14.4 \%$ for triglycerides. HDL-cholesterol increased by an $8.0 \%$ average. The major changes in lipid profile were promoted by atorvastatin $20 \mathrm{mg}$ daily. The medication adherence rate decreased over the monitoring period. Adherence rates below $60 \%$ were associated with therapeutic failure, while rates equal to $80 \%$ or higher were associated with the best response to the lipid-lowering drugs.

Conclusion: Adherence to hypolipidemic agents is higher at the beginning of the treatment, but it decreases over time, affecting the achievement of therapeutic goals.
\end{abstract}

Keywords: Medication Adherence; Hypolipidemic Agents; Outcome and Process Assessment (Health Care); Primary Health Care; Brazil

\section{INTRODUCTION}

Dyslipidemia is a metabolic disorder of high prevalence worldwide. It is one of the major risk factors related to cardiovascular disease, whose incidence is increasing in developing countries such as Brazil. ${ }^{1,2}$

The clinical approach to primary prevention to reduce cardiovascular disease risk is founded on life style changes, including reduced intakes of saturated fat, trans fatty acids, cholesterol and carbohydrate; increased physical activity and weight control. ${ }^{2-5}$ Drug therapy is applied to reduce plasma lipids levels when these modifications fail to control the dyslipidemia. ${ }^{2}$

Numerous studies have shown the benefit of statins in reducing the mortality and morbidity associated with cardiovascular disease. ${ }^{5-9}$

The success of drug therapy for the control, prevention or cure of any disease, especially the chronic ones, depends on the patient's adherence to the treatment. ${ }^{10-12}$ Non-adherence to drug therapy is a principal cause of treatment failure ${ }^{11}$ and is considered a high priority public health issue. $^{12}$

Adherence to treatment is an active, intentional and responsible process of care in which patient's degree of compliance with the health professionals' recommendations. ${ }^{13-15}$ It implies two different behaviors. First means the duration of dosing before patient's premature interruption of treatment, On the other hand, good quality of execution, which describes the daily patterns of patient adherence behavior. $^{13}$

Medication adherence can be characterized either by direct or indirect methods. Direct methods are designed to detect the therapeutic drug or its metabolites in the patients' biological fluids. On other hand, indirect methods mainly include interviews, pill counting, medication electronic monitoring systems and Medication Possession Ratio (MPR) evaluation. ${ }^{11,15} \quad$ MPR considers the amount of times the patient takes out medicines from the health service pharmacy. This procedure to assess patient adherence applies particularly to the public healthcare service, considering that patients must always take their medicines in the same healthcare center. It represents the patient's willingness to comply with his treatment and has been associated with the treatment success. ${ }^{15-20}$ The absence of a gold standard to measure
Cassia CUNICO. MSc. Municipal Health of the São State of Santa Catarina. Florianópolis (Brazil). Geraldo PICHETH. PhD. Professor in the Department of Medical Pathology, Federal University of Parana (UFPR), Curitiba, PR (Brazil).

Cassyano Januário CORRER. PhD. Professor in the Department of Pharmacy, Federal University of Parana (UFPR), Curitiba, PR (Brazil).

Marileia SCARTEZINI. PhD. Professor in the Department of Medical Pathology, Federal University of Parana (UFPR), Curitiba, PR (Brazil). 
adherence and the use of self-report methods hamper adherence research and the assessment of interventions provided. ${ }^{21}$ However, electronic monitoring and pill count have shown the best validity to assess adherence. ${ }^{11}$

Adherence is influenced by many demographic factors, such as gender, age, race, socioeconomic status and pre-existing cardiovascular disease. ${ }^{22,23,25}$ Others including lack of adequate knowledge about medication and treatment goals, beliefs about the medication, complex regimens that are difficult to manage and side effects can play important roles in predicting adherence. ${ }^{24,25}$

In addition to these patient factors, health care system factors, such as access to care, may influence a patient's likelihood to take their medications to improve adherence. ${ }^{22}$ Pharmacists are one of the most utilized members of the health care team due to their ease of accessibility to the general patient population. ${ }^{26}$ There are many opportunities for the pharmacists to become involved in lipid management, such as patient education, lipid levels rechecked, decreasing cardiovascular disease risk factors, along with counseling on adverse effects, administration times and drug interactions. ${ }^{5}$ Pharmacists can promote medication adherence and take part in enhancing continuity of care among healthcare professionals in the community. ${ }^{27}$

This study aims to evaluate the relationship between adherence rate to hypolipidemic agents assessed by MPR and therapeutic effectiveness, for patients whose treatment has been delivered at the primary care level in Brazilian Public Health System.

\section{METHODS}

A retrospective analysis of medical records of 417 active patients of Brazilian Health System was carried out. All of them were registered in the state health program for access to hypolipidemic medication. The study was conducted in twenty-two cities in the far-west region of the State of Santa Catarina, Brazil.

Data collection was carried out by the indirect method using a form developed by the authors. This form consists of structured interview based on standardized information by the Brazilian Health System, which are required to ensure that patients have access to medication. ${ }^{28}$ The data from the structured interview form were obtained from standardized information registered on medical records and pharmacy records.

Patients with incomplete medical records were excluded, as well as those who had left the hypolipidemic agents therapy before the first followup evaluation, and those with monitoring tests dated earlier than 30 days or later than 46 months from the treatment beginning.

The Information data collected in the form were age, gender, weight, height, date of treatment beginning, type of hypolipidemic agent, dosage regimen and changes made in the treatment during the study period. The body mass index (BMI) was calculated and expressed in $\mathrm{kg} / \mathrm{m}^{2}$. The presence / absence of comorbidities such as high blood pressure, type 2 diabetes mellitus, chronic kidney disease, liver disease, hypothyroidism and obesity was identified according to the clinical notes in each patient's medical file.

The serum laboratory tests for total cholesterol, triglycerides, HDL-cholesterol, alanine aminotransferase and fasting plasma glucose were performed in the automated system Cobas mira (Roche Diagnostic) with reagents, calibrators and controls purchased from Labtest Diagnostics SA (Brazil). The LDL-cholesterol was estimated by the Friedewald equation. Thyroid-stimulating hormone was measured by automated chemiluminescence with all reagents and equipment provide by Abbott Diagnostics (Architect Ci8200, Abbott Diagnostic Laboratory, Brazil).

The lipid profile results were evaluated according to the treatment goals established by the Brazilian Society of Cardiology $(2001)^{29}$, that is similar to the American Heart Association, and its recommendations for preventive therapy. ${ }^{1}$ To calculate the amount of time the treatment had been taken, it was considered the time between the first and last medication dispensing. The lipid-lowering therapeutic effectiveness was evaluated for the time elapsing between the beginning of the treatment and the first monitoring assessment for simvastatin $10 \mathrm{mg}, 20 \mathrm{mg}, 40 \mathrm{mg}$ and atorvastatin $10 \mathrm{mg}$ and $20 \mathrm{mg}$ daily. The difference seen in the serum concentration of the lipid profile elements during that period was calculated in percentage. The rate of adherence to the treatment was evaluated based on the patient's medication possession ratio of the hypolipidemic agents, according the following formula ${ }^{19}$.

Adherence rate $(\%)=\frac{\text { Tabiets dispensed } X 100}{\text { Tabiets to be dispensed }}$

Patients with adherence rate $80 \%$ or above were considered to have good adherence to the treatment. ${ }^{19,20}$

Kolmogorov-Smirnov Test was used for normality test, before selecting the statistical tests. Continuous variables have been shown as mean and standard deviation or median (interquartile range), as appropriate. For variables with normal distribution, Student t-test (independent) was applied to compare means between two groups and ANOVA was used for three or more groups. Wilcoxon test was applied to compare means of dependent groups for non-parametric variables, and Mann-Whitney $U$ test was applied to compare nonparametric variables between two independent groups. For three or more groups, Kruskal-Wallis test was used. For the comparison of categorical variables, Fisher Exact test (two-tailed) or chisquare was employed as appropriated. Results were considered significant with a probability less than $5 \% \quad(p<0.05)$. Statistical analyses were performed with SPSS software v.17.0 (Statistical Package of Social Science). 
Cunico C, Picheth G, Correr CJ, Scartezini M. Assessing the adherence to and the therapeutic effectiveness of hypolipidemic agents in a population of patients in Brazil: a retrospective cohort study. Pharmacy Practice 2014 AprJun;12(2):378.

\begin{tabular}{|c|c|c|c|c|}
\hline Variables & $\begin{array}{c}\text { All patients } \\
(n=417)\end{array}$ & $\begin{array}{l}\text { Male group } \\
(n=158)\end{array}$ & $\begin{array}{c}\text { Female group } \\
(n=259)\end{array}$ & P-value \\
\hline Age in years (SD) & $61.0(11.5)$ & $58(11.9)$ & $62(10.9)$ & 0.001 \\
\hline BMl in $\mathrm{kg} / \mathrm{m}^{2}(\mathrm{SD})$ & $28.1(4.6)$ & $28.0(4.0)$ & $28.1(4.9)$ & 0.920 \\
\hline $\begin{array}{r}\text { Euro-Brazilians } \\
\text { Afro-Brazilians }\end{array}$ & $\begin{array}{c}354(84.8) \\
63(15.2) \\
\end{array}$ & $\begin{array}{l}134(84.8) \\
24(15.2) \\
\end{array}$ & $\begin{array}{c}220(84.9) \\
39(15.1) \\
\end{array}$ & $\begin{array}{l}0.756^{*} \\
0.438^{*}\end{array}$ \\
\hline $\begin{array}{r}\text { High Blood Pressure } \\
\text { Diabetes mellitus type } 2 \\
\text { Obesity } \\
\text { Hypothyroidism } \\
\text { Kidney disease } \\
\text { Hepatic disease }\end{array}$ & $\begin{array}{c}346(83.0) \\
121(29.0) \\
57(13.7) \\
28(6.7) \\
6(1.4) \\
3(0.7) \\
\end{array}$ & $\begin{array}{l}130(82.3) \\
42(26.6) \\
18(11.4) \\
4(2.5) \\
3(1.2) \\
2(1.3) \\
\end{array}$ & $\begin{array}{l}216(83.4) \\
79(30.5) \\
39(15.1) \\
24(9.3) \\
3(1.2) \\
1(0.4)\end{array}$ & $\begin{array}{l}0.789^{*} \\
0.437^{*} \\
0.308^{*} \\
0.008^{*} \\
0.677^{*} \\
0.560^{*}\end{array}$ \\
\hline $\begin{array}{c}\text { Simvastatin } \\
\text { Atorvastatin } \\
\text { Others }^{\text {b }}\end{array}$ & $\begin{array}{c}310(74.3) \\
75(18.0) \\
32(7.7) \\
\end{array}$ & $\begin{array}{l}111(70.3) \\
29(18.4) \\
18(11.3) \\
\end{array}$ & $\begin{array}{c}199(76.8) \\
46(17.8) \\
14(5.4) \\
\end{array}$ & $\begin{array}{l}0.165^{\star} \\
0.896^{*} \\
0.372^{*}\end{array}$ \\
\hline Adherence rate to the treatment $\geq 80 \%, \mathrm{n} \mathrm{( \% )}$ & $386(92.6)$ & $147(93.0)$ & $239(92.2)$ & $0,774^{*}$ \\
\hline \multicolumn{5}{|c|}{$\begin{array}{l}\text { The values were mean } \pm 1 \text {-standard deviation or } n(\%) \text {. } \\
\text { P-value: Mann-Whitney } U \text { test or }\left(^{*}\right) \text { Fisher Exact test (two-tailed). } \\
\left({ }^{a}\right) \text { Comorbidities were identified according to the registration in each patient's medical record (presence / absence). } \\
\left.\text { ( }{ }^{b}\right) \text { Others hypolipidemic agent were Ciprofibrate }(3.4 \%) \text {, Gemfibrozil }(2.6 \%) \text {, Bezafibrate }(1.2 \%) \text { and Lovastatin }(0.5 \%) \text {, } \\
\text { Adherence rate to the treatment }(\%)=\text { (Number of tablets dispensed in the period X 100)/Quantity of tablets which should have } \\
\text { been dispensed. }\end{array}$} \\
\hline
\end{tabular}

This study was approved by the Ethics Committee on Human Research of the Health Science Department, from Federal University of Paraná (CEP / SD: 962.087.10.07 and CAE: 3083.0.000.091-10).

\section{RESULTS}

The characteristics of the patients included in the study group are shown in Table 1. The sample consisted of 417 patients, most of them were women $(62.1 \%)$. The median Body Mass Index was $27.7 \mathrm{~kg} / \mathrm{m}^{2}$. The most frequent comorbidities for both genders were hypertension (83\%) and type 2 Diabetes mellitus (29\%), followed by obesity $(13.7 \%)$, hypothyroidism $(6.7 \%)$, kidney disease $(1.4 \%)$ and hepatic disease $(0.7 \%)$. The statins were the most used hypolipidemic class (92.8\%), and simvastatin $20 \mathrm{mg}$ daily was the most frequent treatment prescribed. Ciprofibrate $100 \mathrm{mg}$ daily was the most prescribed fibrate $(3.4 \%)$.

Serum levels at baseline and the first monitoring laboratory tests of the studied group are shown in Table 2.

Serum level of total cholesterol, triglycerides, HDLcholesterol and LDL-cholesterol were significantly lower $(p<0.05)$ in the follow-up evaluation, when compared to the serum dosages at the beginning of the treatment. Serum levels of alanine aminotransferase, thyroid-stimulating hormone and fasting plasma glucose were not significantly different $(p>0.05)$ in the same period.

Our study shown that until the first follow-up evaluation, in average eight months after the start of the treatment, it was verified that $92.6 \%$ of patients achieved an adherence rate of $80 \%$ or above. At the first monitoring time the number of patients with treatment adherence rate of $80 \%$ or above was significantly higher $(p<0.001)$ in patients aged more than $65(94.7 \%)$ when compared to those $<65$ years old $(91.0 \%)$. The adherence rate $80 \%$ or above was not different when the overall time was considered $(84.9 \%)$. As to the evaluation of the full-length treatment period (19.7 months in average), the number of patients who got adherence $80 \%$ or above decreased to $82.6 \%$.

The therapeutic effectiveness of hypolipidemic agents in the population of the study is shown in Figure 1. The evaluation of hypolipidemic therapeutic effectiveness in the studied population shown a decrease in lipid profile serum concentration by daily using the drug simvastatin 10 $\mathrm{mg}, 20 \mathrm{mg}, 40 \mathrm{mg}$ and atorvastatin $10 \mathrm{mg}$ and 20 $\mathrm{mg}$. The greatest reduction of total cholesterol (17\%), LDL-cholesterol (27\%) and triglycerides $(12 \%)$ was obtained with the use of atorvastatin 20 $\mathrm{mg} /$ day. For HDL-cholesterol, the best result was achieved with simvastatin $20 \mathrm{mg} \mathrm{/}$ day (an increasing of $8 \%$ ).

\begin{tabular}{|l|c|c|c|}
\hline \multicolumn{1}{|c|}{ Table 2. Serum levels at baseline and the first monitoring of laboratory tests of the studied group. } \\
\hline \multicolumn{1}{|c|}{ Variables } & Baseline & First monitoring & P-value \\
\hline Total Cholesterol $(\mathrm{mg} / \mathrm{dL})$ & $232.0(83.0-415.0)$ & $196.0(87.0-386.0)$ & $<0.001$ \\
\hline LDL- cholesterol $(\mathrm{mg} / \mathrm{dL})$ & $142.0(20.0-327.6)$ & $115.1(14.2-281.0)$ & $<0.001$ \\
\hline $\mathrm{HDL}$-cholesterol $(\mathrm{mg} / \mathrm{dL})$ & $47.0(15.0-103.0)$ & $49.0(16.0-113.0)$ & $<0.001$ \\
\hline Triglycerides $(\mathrm{mg} / \mathrm{dL})$ & $170.0(56.0-1564.0)$ & $143.0(48.0-1630.0)$ & $<0.001$ \\
\hline Fasting Plasma Glucose $(\mathrm{mg} / \mathrm{dL})$ & $94.0(60.0-420.0)$ & $94(42.0-325.0)$ & 0.175 \\
\hline Serum Creatinine $(\mathrm{mg} / \mathrm{dL})$ & $1.0(0.5-9.7)$ & $1.0(0.4-3.9)$ & 0.587 \\
\hline Alanine Aminotransferase $(\mathrm{U} / \mathrm{L})$ & $20.0(5.0-148.0)$ & $21.0(7.0-66.0)$ & 0.067 \\
\hline Thyroid-stimulating Hormone $(\mu U / \mathrm{mL})$ & $1.7(0-52.5)$ & $1.9(0.2-16.4)$ & 0.886 \\
\hline $\begin{array}{l}\text { The values were median (interquartile range) } \\
\text { Sample size 417 subjects; first monitoring 8.3 months (average) }\end{array}$ \\
P-value: Mann-Whitney U test.
\end{tabular}



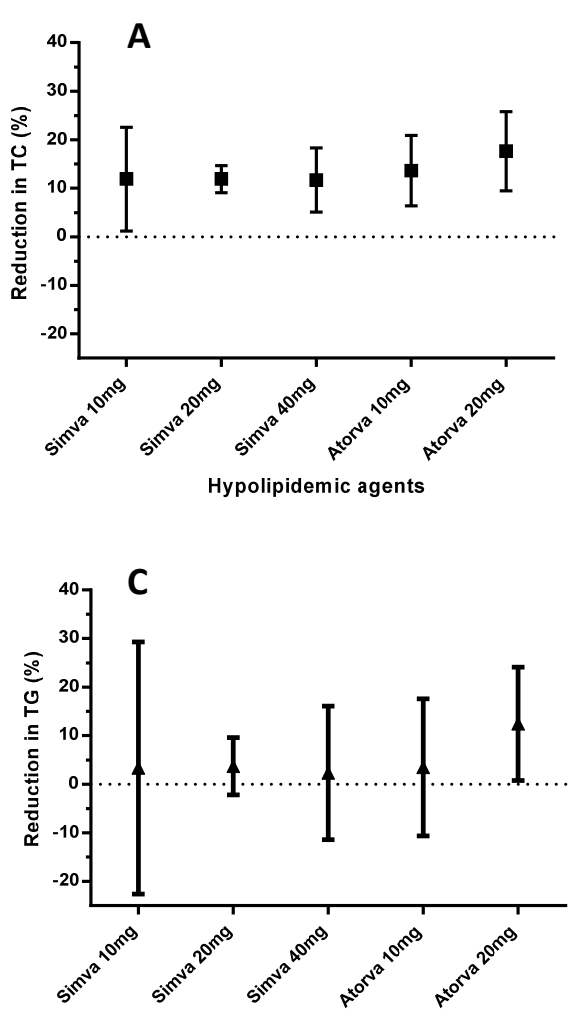

Hypolipidemic agents
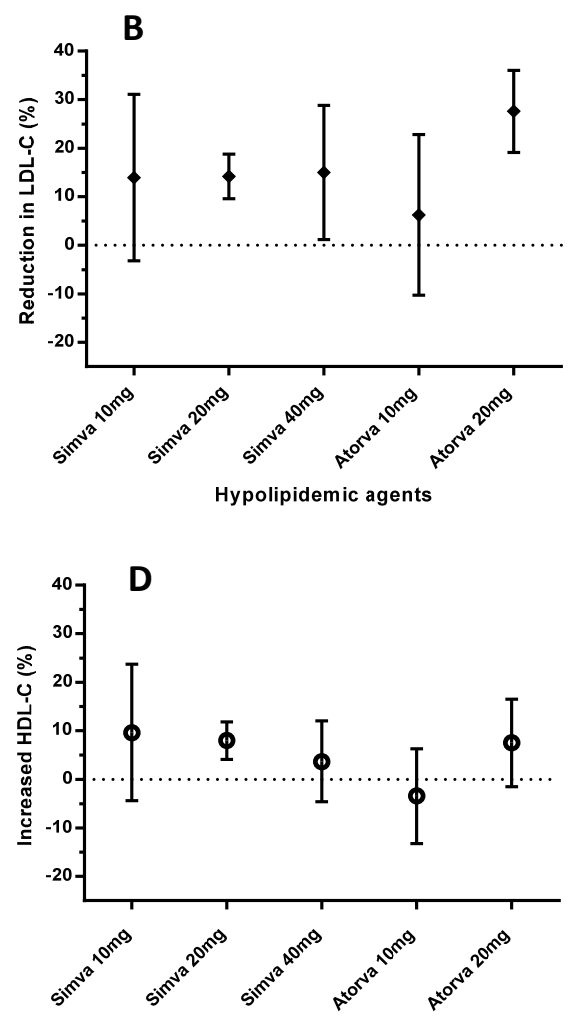

Hypolipidemic agents

Figure 1. Changes in serum lipid profile after treatment with hypolipidemic agents at different dosages regimens. Values are the mean percentage reduction or increase of the analyses levels and the vertical bars represent $95 \%$ confidence interval, when comparing the results of the lipid profile before and after hypolipidemic therapy. Sample size 417 individuals. The dotted line (zero) indicates no change after treatment.

A. Reduction in serum total cholesterol (TC).

B. Reduction in serum concentration of LDL-cholesterol (LDL-C).

C. Reduction in serum concentration of triglycerides (TG).

D. Increased serum concentration of HDL-cholesterol (HDL-C).

Hypolipidemic agents: simvastatin $10 \mathrm{mg}$ (Simva 10mg), simvastatin $20 \mathrm{mg}$ (Simva 20mg), simvastatin $40 \mathrm{mg}$

(Simva $40 \mathrm{mg}$ ), atorvastatin $10 \mathrm{mg}$ (Atorva $10 \mathrm{mg}$ ) and atorvastatin $20 \mathrm{mg}$ (Atorva 20mg).

The relation between the adherence rate to hypolipidemic therapy and the reduction obtained for total cholesterol and LDL-cholesterol, in the period between the start of the treatment and the first clinical monitoring examinations, is shown in Figure 2.

Patients who had adherence rate to hypolipidemic therapy lower than $55 \%$ did not present any reduction in total cholesterol. For the patients who had adherence rate from 55 to $80 \%$, the reduction for total cholesterol was $0-7 \%$; while the greatest reduction, of about $11 \%$, was observed for the ones with an adherence rate higher than $80 \%$. For LDLcholesterol, adherence rates to the treatment lower than $60 \%$ had no therapeutic effectiveness. A significant reduction (14\%) of LDL-cholesterol was only obtained with adherence rates higher than $80 \%$.

\section{DISCUSSION}

This was a retrospective cohort study that shown that lipid profile serum concentration was significantly reduced after the use of hypolipidemic therapy by patients with good to optimal medication adherence. To our best knowledge, this is the first study regarding the evaluation of the adherence rate for hypolipidemic agents in a Brazilian population assisted by the Public Health Service.

In this study, the greatest reduction of total cholesterol, LDL-cholesterol (and triglycerides was obtained with the use of atorvastatin $20 \mathrm{mg} /$ day. Similarly, a study by Jones et al. ${ }^{30}$ with 534 hypercholesterolemic patients, revealed that atorvastatin $20 \mathrm{mg}$ daily, produced greater $(p \leq 0.01)$ reductions in total cholesterol and in LDLcholesterol $(46 \%)$, than other hypolipidemic agents like simvastatin. On the other hand, Brown et al. ${ }^{31}$, in a study that compared the efficacy of atorvastatin, fluvastatin, lovastatin, and simvastatin with 318 patients with atherosclerosis, verified that atorvastatin $10 \mathrm{mg}$ daily produced significantly greater decreases $(p<0.05)$ in plasma LDLcholesterol than the other treatments. Consistent results about atorvastatin $10 \mathrm{mg}$ were reported by Andrews et $\mathrm{al}^{32}$ They demonstrated that atorvastatin $10 \mathrm{mg}$ daily achieved the greatest 

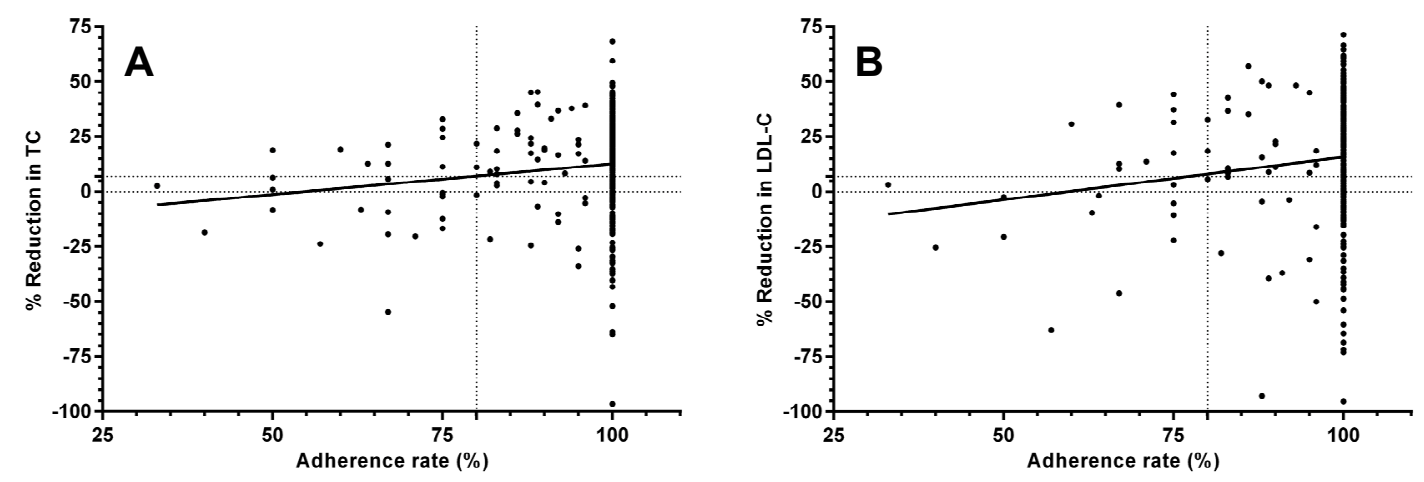

Figure 2. The relationship between the adherence rate of the hypolipidemic therapy to serum lipids biomarkers The points represent the percentage reduction of the analytes in relation to the percentage of patient adherence to hypolipidemic therapy $(n=417)$. The continuous line represents the regression between all points.

A. Reduction in serum total cholesterol (TC). The horizontal dotted line (zero) indicates no change after treatment. The horizontal dotted line $(7 \%)$ indicates the reduction of total cholesterol obtained for adherence rate between 55 $80 \%$. The vertical dotted line indicates the $80 \%$ adherence rate.

B. Reduction in the concentration of LDL cholesterol (LDL-C). The horizontal dotted line (zero) indicates no change after treatment. The horizontal dotted line $(7 \%)$ indicates the reduction of LDL cholesterol obtained for adherence rate between $60-80 \%$. The vertical dotted line indicates $80 \%$ adherence rate.

mean reduction in LDL cholesterol $(36 \%, \mathrm{SD}=11 \%$ at 6 weeks) than pravastatin $10 \mathrm{mg}$, simvastatin 10 $\mathrm{mg}$, fluvastatin $20 \mathrm{mg}$ and lovastatin $20 \mathrm{mg}$, in the same period.

According to Brazilian Society of Cardiology ${ }^{2}$, statins may reduce LDL-cholesterol from $15 \%$ to $55 \%$ and triglycerides from $7 \%$ to $28 \%$. They also may increase HDL-cholesterol from $2 \%$ to $10 \%$. The expected reduction depends upon the drug and the dosage regimen used. Therefore, the expected reduction of LDL-cholesterol, for simvastatin $20 \mathrm{mg}$ to $80 \mathrm{mg}$, is from $27 \%$ to $42 \%$; whereas for atorvastatin 10 to $80 \mathrm{mg}$, the expected reduction for the same parameter is from $37 \%$ to $55 \%$. Considering the results of simvastatin $20 \mathrm{mg}$ for the population under study, the reductions obtained for LDL-cholesterol and triglycerides were lower than the theoretical effectiveness described in the literature. For HDL-cholesterol the obtained results are consistent with the expectations.

Cardiovascular medications adherence is often low. ${ }^{33}$ For hypolipidemic therapy, the limit value (cut off value) for adherence rate is $80 \% .^{19,20,34,35}$ It is considered good adherence when the adherence rate to the treatment $80 \%$ or above and poor adherence when its $<80 \%$. ${ }^{1,20,34,35}$

In our study, a good adherence was observed in about $90 \%$ of the patients at the first 8 months of therapy and reduced to about $80 \%$ after 20 months. The observed reduction in patient adherence over the time can be a result of several interacting factors, like side effects, patient misunderstanding about treatment and lack of appropriate patient monitoring.

A study by Andrade et al. ${ }^{36}$ with users of hypolipidemic therapy, revealed that the rate of adherence reduces $4-15 \%$ in the first year of treatment and approximately 11 to $30 \%$ when the clinical monitoring lasts five years or more. Similarly, Applegate 37 in his study with elderly patients', verified that adherence to statin therapy declined more than $25 \%$ in the first 6 months after the original prescription, with further declines in adherence the longer the cohort was followed. Benner et al. ${ }^{34}$ also reported a reduction of medication adherence in the long-term therapy. Their study reported that $39 \%$ of their patients shown adherence rate above $80 \%$ after 12 months of treatment with statins. These authors have also verified that patients with comorbidities, such as hypertension, diabetes or a past history with cardiovascular disease, have a better persistence for hypolipidemic therapy. Catalan et al. ${ }^{23}$ shown that a higher index of chronic morbidity and preexisting cardiovascular disease were predictive of longer persistence on statin medication. Consistent results were reported by Jackevicius et al. ${ }^{38}$ The results of their study shown that elderly patients' adherence to statin therapy continually reduced from initiation of therapy through 2 years follow-up and shown that patients at higher risk for cardiovascular disease were more adherent to therapy than those patients treated for primary prevention. Ruokoniemi et al. ${ }^{35}$ have verified therapeutic adherence rates to statins over $80 \%$ in more than $50 \%$ of their studied population, and also that older patients with comorbidities have a higher adherence to the treatment. Avorn et al. ${ }^{39}$ have not identified any therapeutic adherence difference between genders, which is consistent with our results.

In a study to implement pharmaceutical care program to improve medication adherence in new users of statin, the authors verified that pharmacist has an important role to play in ensuring that drug therapy is appropriate and effective. ${ }^{40}$ They compared discontinuation of statin therapy over time between patients in the pharmaceutical care and usual care groups. They found that patients in the pharmaceutical care group were more likely to persist with treatment compared to patients in the usual care group. ${ }^{40}$

A recent survey that sought to determine views of pharmacist effectiveness and impact on health care delivery found that $96 \%$ of respondents reported 
benefits, including improved disease management outcomes, increased return on investment, and increased access to patient care. ${ }^{41}$

Another study about adverse drug events suggests that pharmacist intervention decreases $34 \%$ the risk of adverse drug events and medication errors in patients with cardiovascular disease. ${ }^{42}$

A review of several studies to quantify the impact of pharmacist interventions in hyperlipidemia management ${ }^{43}$ and in cardiovascular and renal disease $^{44}$, evidenced that total cholesterol is sensitive to pharmacist interventions ${ }^{43}$, and there are improvements in cardiovascular and renal outcomes. $^{44} \quad$ Furthermore, patient-specific recommendations made by pharmacist can positively affect prescribing habits and make steps to improve patient safety. ${ }^{45}$

Nevertheless, there are limitations in this study. First, a potential limitation was the impossibility to determine if the patients effectively used the hypolipidemic drugs that were dispensed from the Brazilian Public Health System. Second, we did not consider those patients who might have been taken a statin and a fibrate simultaneously. Third, we did not compare the therapy adherence between patients without any history of cardiovascular event with those who had any previous cardiovascular events.

\section{CONCLUSIONS}

Lipid profile presented a significant reduction in serum total cholesterol, LDL-cholesterol and triglycerides, as well as an increase in HDLcholesterol in patients with good to optimal medication adherence. A medication possession ratio above $80 \%$ was related to the best health outcomes.

The adherence rate assessment by recording the pills that a patient received shows to be a simple, low cost and effective process to assess therapeutic effectiveness for hypolipidemic drugs and a potential predicator of the treatment effectiveness.

The access to the medicines, which are supplied free of charge by the Brazilian Health System, as an isolated action in the treatment of dyslipidemia, does not ensure a successful drug therapy outcome in the long-term. On the contrary, patients' adherence and clinical outcomes monitoring can go together with drug dispensing all over the treatment in order to ensure its therapeutic success. The pharmacists have the opportunity to promote health and disease prevention through improved treatment adherence.

\section{CONFLICT OF INTEREST}

The authors declare not having any conflict of interest.

\section{EVALUANDO LA ADHERENCIA Y LA EFECTIVIDAD TERAPÉUTICA DE LOS HIPOLIPEMIANTES EN UNA POBLACIÓN DE PACIENTES EN BRASIL: ESTUDIO DE COHORTE RETROSPECTIVA}

\section{RESUMEN}

Objetivo: Evaluar la relación entre la adherencia del paciente y la efectividad terapéutica de los hipolipemiantes en la práctica clínica.

Métodos: Se realizó un estudio retrospectivo de 417 pacientes que usaban hipolipemiantes (simvastatina, atorvastatina) entre 2003 y 2010. La población estudiada estaba compuesta de pacientes atendidos en el Servicio Público de Salud de la región del oeste lejano del estado de Santa Catarina, Brasil. Se usó como medida de adherencia el ratio de posesión de medicación obtenido de los datos de consumo en la farmacia. La efectividad terapéutica se evaluó en base a la diferencia obtenida en los niveles séricos de colesterol total, colesterol-LDL, colesterol-HDL y triglicéridos antes y después de tomar el medicamento en una media de tiempo de 8,3 meses. Resultados: Después del tratamiento con hipolipemiantes, se observó una reducción del 14,3\% para el colesterol total, $19,6 \%$ para el LDL, y $14,4 \%$ para los triglicéridos. El HDL aumentó en una media del $8,0 \%$. Los mayores cambios del perfil lipídico fueron promovidos por la atorvastatina $20 \mathrm{mg}$ diarios. La tasa de adherencia a la medicación disminuyó durante el periodo seguido. Las tasas de adherencia por debajo del $60 \%$ estaban asociadas con fracaso terapéutico, mientras que las tasas del $80 \%$ o superiores estaban asociadas a la mejor respuesta a los hipolipemiantes.

Conclusión: La adherencia a los hipolipemiantes fue mayor al principio del tratamiento, pero disminuye a lo largo de éste, afectando a la consecución de los objetivos terapéuticos. Los procedimientos sistemáticos de monitorización de la tasa de adherencia y la evaluación del perfil lipídico por el farmacéutico

Palabras clave: Cumplimiento de la Medicación; Hipolipemiantes; Evaluación de Procesos y Resultados (Atención de Salud); Atención Primaria de Salud; Brasil

\section{References}

1. Roger VL, Go AS, Lloyd-Jones DM, Adams RJ, Berry JD, Brown TM, Carnethon MR, Dai S, de Simone G, Ford ES, Fox CS, Fullerton HJ, Gillespie C, Greenlund KJ, Hailpern SM, Heit JA, Ho PM, Howard VJ, Kissela BM, Kittner SJ, Lackland DT, Lichtman JH, Lisabeth LD, Makuc DM, Marcus GM, Marelli A, Matchar DB, McDermott MM, Meigs JB, Moy CS, Mozaffarian D, Mussolino ME, Nichol G, Paynter NP, Rosamond WD, Sorlie PD, Stafford RS, Turan TN, Turner MB, Wong ND, Wylie-Rosett J; American Heart Association Statistics Committee and Stroke Statistics Subcommittee. Heart disease and stroke statistics--2011 update: a report from the American Heart Association. Circulation. 2011;123(4):e18-e209. doi: 10.1161/CIR.0b013e3182009701

2 Sposito AC, Caramelli B, Fonseca FA, Bertolami MC, Afiune Neto A, Souza AD, Lottenberg AM, Chacra AP, Faludi AA, Loures-Vale AA, Carvalho AC, Duncan B, Gelonese B, Polanczyk C, Rodrigues Sobrinho CR, Scherr C, Karla C, Armaganijan D, Moriguchi E, Saraiva F, Pichetti G, Xavier HT, Chaves H, Borges JL, Diament J, Guimarães JI, Nicolau JC, dos Santos JE, de Lima JJ, Vieira JL, Novazzi JP, Faria Neto JR, Torres KP, Pinto Lde A, Bricarello L, Bodanese LC, Introcaso L, Malachias MV, Izar MC, Magalhães ME, Schmidt MI, Scartezini M, Nobre M, Foppa M, Forti NA, 
Cunico C, Picheth G, Correr CJ, Scartezini M. Assessing the adherence to and the therapeutic effectiveness of hypolipidemic agents in a population of patients in Brazil: a retrospective cohort study. Pharmacy Practice 2014 AprJun;12(2):378

Berwanger O, Gebara OC, Coelho OR, Maranhão RC, dos Santos Filho RD, Costa RP, Barreto S, Kaiser S, Ihara S, Carvalho Td, Martinez TL, Relvas WG, Salgado W; Sociedade Brasileira de Cardiologia. [IV Brazilian Guideline for Dyslipidemia and Atherosclerosis prevention: Department of Atherosclerosis of Brazilian Society of Cardiology]. Arq Bras Cardiol. 2007;88(Suppl 1):2-19.

3 Expert Panel on Detection, Evaluation, and Treatment of High Blood Cholesterol in Adults. Executive Summary of The Third Report of The National Cholesterol Education Program (NCEP) Expert Panel on Detection, Evaluation, And Treatment of High Blood Cholesterol In Adults (Adult Treatment Panel III). JAMA. 2001 May 16;285(19):2486-2497.

4 Xavier HT, Izar MC, Faria Neto JR, Assad MH, Rocha VZ, Sposito AC, Fonseca FA, dos Santos JE, Santos RD, Bertolami MC, Faludi AA, Martinez TL, Diament J, Guimarães A, Forti NA, Moriguchi E, Chagas AC, Coelho OR, Ramires JA. V Diretriz brasileira de dislipidemia e prevenção da aterosclerose. Arq Bras Cardiol. 2013 Oct;101(4 Suppl 1):1-20. doi: 10.5935/abc.2013S010

5 Olson KL, Potts LA. Role of the pharmacist in the management of dyslipidemia. J Pharm Pract. 2006;19(2):94-102. doi: 10.1177/0897190006290046

6 Ward S, Lloyd Jones M, Pandor A, Holmes M, Ara R, Ryan A, Yeo W, Payne N. A systematic review and economic evaluation of statins for the prevention of coronary events. Health Technol Assess. 2007;11(14):1-160

7 Baigent C, Keech A, Kearney PM, Blackwell L, Buck G, Pollicino C, Kirby A, Sourjina T, Peto R, Collins R, Simes R; Cholesterol Treatment Trialists' (CTT) Collaborators. Efficacy and safety of cholesterol-lowering treatment: prospective meta-analysis of data from 90056 participants in 14 randomised trials of statins. Lancet. 2005;366(9493):1267-1278.

8 Li ZY, Tang TY, Jiang F, Zhang Y, Gillard JH. Reduction in arterial wall strain with aggressive lipid-lowering therapy in patients with carotid artery disease. Circ J. 2011;75(6):1486-1492.

9 Sposito AR, Aguiar Filho GB, Aarão AR, Sousa FTT, Bertolami MC. Statins in acute coronary syndromes. Arq Bras Cardiol. 2011;97(4):350-356.

10 Leite SN, Vasconcellos MPC. Adherence to prescribed therapy: points for concepts and presuppositions discussion. Cienc Saude Coletiva. 2003;8(3):775-782.

11 Fikri-Benbrahim N, García-Cárdenas V, Sáez-Benito L, Gastelurrutia MA, Faus MJ. Adherence: a review of education, research, practice and policy in Spain. Pharm Pract (Granada). 2009;7(3):125-138.

12 WHO. Adherence to long-term therapies. Evidence for actions. Geneve: World health Organization. 2003 http://www.who.int/chp/knowledge/publications/adherence_report/en/ (accessed 3-29-2014).

13 Schneider MP, Krummenacher I, Figueiredo H, Marquis J, Bugnon O. Adherence: a review of education, research, practice and policy in Switzerland. Pharm Pract (Granada). 2009;7(2):63-73.

14 Haugbølle LS, Herborg H. Adherence to treatment: practice, education and research in Danish community pharmacy. Pharm Pract (Granada). 2009;7(4):185-194.

15 Osterberg L, Blaschke T. Adherence to Medication. N Engl J Med. 2005;353(5):487-497

16 Cooper J, Hall L, Penland A, Krueger A, May J. Measuring medication adherence. Popul Health Manag. 2009;12(1):2530 .

17 Dezii CM. Persistence with drug therapy: a practical approach using administrative claims data. Manag Care. 2001;10(2):42-45.

18 Haynes RB, McDonald HP, Garg AX. Helping patients follow prescribed treatment: clinical applications. JAMA. 2002;288(22):2880-2883.

19 Mabotuwana T, Warren J, Harrison J, Kenealy T. What can primary care prescribing data tell us about individual adherence to long-term medication? - Comparison to pharmacy dispensing data. Pharmacoepidemiol Drug Saf. 2009;18(10):956-964. doi: 10.1002/pds.1803

20 Morisky DE, Green LW, Levine DM. Concurrent and predictive validity of a self-reported measure of medication adherence. Med Care. 1986;24(1):67-74.

21 Aslani P, Krass I. Adherence: a review of education, research, practice and policy in Australia. Pharm Pract (Granada). 2009;7(1):1-10.

22. Mauskop A, Borden WB. Predictors of statin adherence. Curr Cardiol Rep. 2011;13(6):553-558. doi: 10.1007/s11886011-0221-2

23. Catalan VS, LeLorier J. Predictors of long-term persistence on statins in a subsidized clinical population. Value Health. 2000;3(6):417-426.

24 Rickles NM, Brown TA, McGivney MS, Snyder ME, White KA. Adherence: a review of education, research, practice, and policy in the United States. Pharm Pract (Granada). 2010;8(1):1-17.

25 Thunander Sundbom L, Bingefors K. Women and men report different behaviours in, and reasons for medication nonadherence:a nationwide Swedish survey. Pharm Pract (Granada). 2012;10(4):207-221.

26 Mangan MN, Powers MF, Lengel AJ. Student Pharmacists' Perceptions of Barriers to Medication Adherence Counseling J Pharm Pract. 2013 Aug;26(4):376-381. doi: 10.1177/0897190012466896

27 Schneider MP, Aslani P. Adherence policy, education and practice - an international perspective. Pharm Pract (Granada). 2010;8(4):209-212.

28 BRASIL. Ministério da Saúde. Secretaria de Assistência à Saúde. Portaria n 1.015 de 23 de dezembro de 2002. Aprova o Protocolo Clínico e Diretrizes Terapêuticas para as Dislipidemias em pacientes de alto risco de desenvolver eventos cardiovasculares. Diário Oficial da União, Brasília, DF, 24 dez. 2002.

29 Santos RD, Giannini SD, Fonseca FH, Moriguchi EH: Sociedade Brasileira de Cardiologia. III Diretrizes brasileiras sobre dislipidemias e diretriz de prevenção da aterosclerose do Departamento de Aterosclerose da Sociedade Brasileira de Cardiologia. Arq Bras Cardiol. 2001;77(supl 3):1-48. 
Cunico C, Picheth G, Correr CJ, Scartezini M. Assessing the adherence to and the therapeutic effectiveness of hypolipidemic agents in a population of patients in Brazil: a retrospective cohort study. Pharmacy Practice 2014 AprJun;12(2):378.

30 Jones $\mathrm{P}$, Kafonek S, Laurora I, Hunninghake D. Comparative dose efficacy study of atorvastatin versus simvastatin, pravastatin, lovastatin, and fluvastatin in patients with hypercholesterolemia (The CURVES Study). Am J Cardiol. 1998;81(5):582-587.

31 Brown AS, Bakker-Arkema RG, Yellen L, Henley RW Jr, Guthrie R, Campbell CF, Koren M, Woo W, McLain R, Black DM. Treating patients with documented atherosclerosis to National Cholesterol Education Program-recommended low density-lipoprotein cholesterol goals with atorvastatin, fluvastatin, lovastatin and simvastatin. J Am Coll Cardiol. 1998;32(3):665-672

32 Andrews TC, Ballantyne CM, Hsia JA, Kramer JH. Achieving and maintaining National Cholesterol Education Program low-density lipoprotein cholesterol goals with five statins. Am J Med. 2001;111(3):185-191.

33 Shalansky SJ, Levy RA, Ignaszewski AP. Self-reported morisky score for identifying nonadherende with cardiovascular medications. Ann Pharmacother. 2004;38(9):1363-1368

34 Benner JS, Glynn RJ, Mogun H, Neumann PJ, Weinstein MC, Avorn J. Long-term persistence in use of statin therapy in elderly patients. JAMA. 2002;288(4):455-461.

35 Ruokoniemi P, Korhonen MJ, Helin-Salmivaara A, Lavikainen P, Jula A, Junnila SY, Kettunen R, Huupponen R. Statin adherence and the risk of major coronary events in patients with diabetes: a nested case-control study. Br J Clin Pharmacol. 2011;71(5):766-776. doi: 10.1111/j.1365-2125.2010.03895.x

36 Andrade SE, Walker AM, Gottlieb LK, Hollenberg NK, Testa MA, Saperia GM, Platt R. Discontinuation of antihyperlipidemic drugs - do rates reported in clinical trials reflect rates in primary care settings? $\mathrm{N}$ Engl $\mathrm{J}$ Med. 1995;332(17):1125-1131.

37 Applegate WB. Elderly patients' adherence to statin therapy. JAMA. 2002;288(4):495-497.

38 Jackevicius CA, Mamdani M, Tu JV. Adherence with statin therapy in elderly patients with and without acute coronary syndromes. JAMA. 2002;288(4):462-467.

39. Avorn J, Monette J, Lacour A, Bohn RL, Monane M, Mogun H, LeLorier J. Persistence of use of lipid-lowering medications. A Cross-National Study. JAMA. 1998;279(18):1458-1462.

40 Eussen SR, van der Elst ME, Klungel OH, Rompelberg CJ, Garssen J, Oosterveld MH, de Boer A, de Gier JJ, Bouvy ML. A pharmaceutical care program to improve adherence to statin therapy: a randomized controlled trial. Ann Pharmacother. 2010;44(12):1905-1913. doi: 10.1345/aph.1P281

41 Giberson S, Yoder S, Lee MP. Improving Patient and Health System Outcomes through Advanced Pharmacy Practice. A Report to the U.S. Surgeon General. Office of the Chief Pharmacist. U.S. Public Health Service, 2011.

42 Murray MD, Ritchey ME, Wu J, Tu W. Effect of a pharmacist on adverse drug events and medication errors in outpatients with cardiovascular disease. Arch Intern Med. 2009;169(8):757-763. doi: 10.1001/archinternmed.2009.59

43 Machado M, Nassor N, Bajcar JM, Guzzo GC, Einarson TR. Sensitivity of patient outcomes to pharmacist interventions. Part III: systematic review and meta-analysis in hyperlipidemia management. Ann Pharmacother. 2008;42(9):11951207. doi: 10.1345/aph.1K618

44 Odum L, Whaley-Connell A. The role of team-based care involving pharmacists to improve cardiovascular and renal outcomes. Cardiorenal Med. 2012;2(4):243-250.

45 Shoulders BR, Franks AS, Barlow PB, Williams JD, Farland MZ. Impact of pharmacists' interventions and simvastatin dose restrictions. Ann Pharmacother. 2014;48(1):54-61. doi: 10.1177/1060028013511323 